\title{
The relationship between the characteristics of the transformational leader and the entrepreneur in South African SMEs
}

\author{
D.J. Visser* \\ Department of Management, Faculty of Economic and Management Sciences, \\ University of the Western Cape, Private Bag X17, Bellville 7535, Republic of South Africa \\ kvisser@uwc.ac.za \\ T.J. de Coning \\ Senior Director, Strategic Initiatives, University of Stellenbosch, \\ Stellenbosch 7600, Republic of South Africa \\ E.v.d.M. Smit \\ Graduate School of Business, University of Stellenbosch, \\ PO Box 610, Bellville 7535, Republic of South Africa
}

Received May 2004

\begin{abstract}
Transformational leadership, as found in large firms can be applied to entrepreneurial leaders in SMEs. Since significant transformation is being brought about in organisations by changes in technology, international competition and workforces which become more diverse, literature proposes that this type of leadership is becoming more important to organisations. Similarly, there is a need for a 'new' style of leadership in South African SMEs, especially those enterprises which display the capacity and capability to enter and compete in world markets. Since the literature clearly indicates that transformational leadership is a behavioural process which can be learned, the purpose of this paper is twofold: firstly, to identify the profile elements of entrepreneurship and transformational leadership in SMEs which, if applied appropriately, will in all probability, lead to organisational innovation; and, secondly, to determine whether entrepreneurs in SMEs in the South African context possess characteristics that manifest them as transformational leaders. It is demonstrated that a significant and positive relationship exists between the characteristics of an entrepreneur and the characteristics of a transformational leader in South African SMEs.
\end{abstract}

*To whom all correspondence should be addressed.

\section{Introduction}

Ever since the late 1980s the world order has been characterised by extraordinary degrees of transformation, manifested by rapid political change, economic restructuring, adaptation to new rules of (international) competition, dynamic technological advancement and intense changes in social order.

In larger enterprises increasing attention has been focused on a dynamic style of leadership which induced dramatic changes in organisations which developed a vision of the future of the organisation, essentially a leadership type analogous to a change agent (catalyst) - a leadership style which requires commitment from others to support that vision (Barling, Slater \& Kelloway, 2000:157; Kelloway \& Barling, 2000:355; Pillai, Schriesheim \& Williams, 1999:650; Waldman, 1987:24).

The theory behind this style of leadership has been developed under the label of transformational leadership. Only after Burn's seminal work on political leaders in 1978, the concept became recognised and accepted in the literature (Tichy \& Devanna, 1997; Bass \& Avolio, 1994; Tichy \& Devanna, 1986:27; Bennis, 1982:54-56; Bass, 1985; Tichy \& Ulrich,
1984:59-84). Organisations with cultural values and norms that reward endeavours such as innovation, development, change and demonstrate respect for the individual, provide environments conducive to the advancement of transformational leadership. Transformational leadership is a systematic process searching for change, innovation and entrepreneurship (Lussier, 2003:413).

For organisations to accommodate these intense environmental changes, as argued by Cromie (2000:10) and Nadler and Tushman (1990:77), adaptation and speed are of essence. South African enterprises, too, are exposed to the environmental variables that bring about rapid changes (Nieman, 2002:446; Visagie, 1997:660; De Coning, 1992:5259).

The economic stagnation and isolation from markets (both nationally and internationally) brought about by inappropriate political ideologies increasingly enforced its stranglehold on South African enterprises (Dobson, 2002:3-8; Nieman, 2002:445-446; Visagie, 1997:660-661; Viviers \& Steyn, 1992:39). For example, the international pariah status of South Africa coupled with sanctions (such as disinvestment and trade boycotts), have prevented enterprises from competing and 
exporting internationally, whilst internally these ideologies had been causal to detachment (and the concomitant loss of opportunities) between black and white sections of the market. De Coning (1992:53) characterises the scenario of lost opportunities in the South African market as the general failure by business people to exploit opportunities due to their insular approaches towards business from, either a 'traditional white business perspective', or a 'traditional black business perspective', respectively.

In an argument similar to, and in support of De Coning's postulation above, Berry, Von Blotnitz, Cassim, Kesper, Rajaratnam and Van Sevenster (2002:5) ascribe the poor performance of SMEs in South Africa to, inter alia, a highly dualistic economy as a result of limited interaction between the black and white sections. Therefore, the isolation from world trends and developments engenders lack of vision and a deviation from reality in the leadership abilities of, inter alia, SMEs (Denton \& Vloeberghs, 2003:86).

Table 1: Themes of leadership
Partly the stagnation can be explained in terms of the behaviour of South Africans themselves, including low productivity of labour and deficiencies in their entrepreneurial behaviours (Berry et al., 2002:5-6). These archaic (or traditional) business perspectives, require an urgent reformulation of basic business philosophies and the realignment of core-values of business, the latter of which influence basic management perceptions (Hisrich \& Drnovsek, 2002:173; Driver, Wood, Segal \& Herrington, 2001:38-48).

The 'different approach' to leadership is presented in Table 1. The statements of the left-hand side of the table bear strong resemblance to the classical approach to leadership. The classical school recommends the retaining of power at the top of the hierarchy; the domination of formal channels of communication; precise allocation of tasks; the full utilisation of written rules, procedures and contractual regulations; and, the rigorous exercise of control by leaders. Carson, Cromie, McGowan and Hill (1995:26) state that in this kind of work environment 'calculative and alienative involvement by employees is the norm'.

\begin{tabular}{l|l}
\hline Less emphasis needed on: & Greater emphasis needed on: \\
\hline Classical school & Transformational leadership \\
Planning & Vision/mission \\
Allocating responsibility & Infusing vision \\
Controlling and problem-solving & Motivating and inspiring \\
Creating, routine and equilibrium & Creating change and innovation \\
Power retention & Empowerment of others \\
Creating compliance & Creating commitment \\
Emphasizing contractual obligations & Stimulating extra effort \\
Detachment and rationality on the part of the leader & Interest in others and intuition on the part of the leader \\
Reactive approach to the environment & Proactive approach to the environment \\
\hline
\end{tabular}

Source: Bryman, A. 1992. Charisma and leadership in organizations. London: Sage. p.111.

On the other side of Table 1, leadership of a transformational nature is less concerned with directing and controlling staff and show more concern with creating conditions conducive for employees to release the potential of individuals who have to contribute to the future development of the organisation. Viewed differently, Robbins (2000:xiii) refers to the paradigm shift of a leader's role to one of dealing with globalisation, diversity, quality, entrepreneurship and organisational learning.

Carson et al. (1995:27) state that ' ... transformative leaders strive to create commitment, interest and motivation from workers in pursuit of a vision to which they subscribe. In a modern world where change in knowledge and markets, together with a demand for individualized service by customers, is so common, rigid controlling bureaucracies are much less likely to meet consumer needs than flexible empowered ventures. Calls for an organisational and managerial approach akin to transformational leadership are not new, but they have a greater sense of urgency in today's rapidly changing, competitive world'.

It is within such a dynamic environment that small and medium-sized enterprises (SMEs) have to operate and function productively. In order to continue and compete in new local and global markets, SMEs will have to manage through periods of rapid incremental (and even revolutionary) change. Viewed differently, if South African SMEs were to grow and expand, their leaders will have to recognise the need for revitalisation, to create a new vision and to institutionalise the changes within their enterprises.

The research question posed in this investigation is to determine whether entrepreneurs in small and medium-sized enterprises (SMEs) in the South African context possess characteristics that manifest them as transformational leaders.

To examine the concept of strategic transformational behaviour in small enterprises, the following hypothesis is proposed: A stochastic relationship exists between the characteristics typically associated with the 'ideal' SME entrepreneur and the characteristics of a transformational leader. 


\section{The profile of a transformational leader and an entrepreneur}

For the purposes of this study the following definitions shall apply for entrepreneurship and transformational leadership, respectively:

Entrepreneurship: Creating something different with value by devoting the necessary time and effort, assuming the accompanying financial, psychic, and social risks, and receiving the resulting rewards of monetary and personal satisfaction.

Transformational leadership: The ability to inspire and motivate followers to achieve results greater than originally planned and for internal awards.

A review of literature on transformational leadership reveals that this 'dynamic style of leadership' has mainly been reported in large corporations in the United States of America, and in enterprises of similar size in the United Kingdom, New Zealand, as well as in government services the USA, Sweden and Israel (Dvir \& Shamir, 2003:327-344; Larsson, Carlstedt, Andersson, Andersson, Danielsson, Johansson, Johansson, Robertsson \& Michel, 2003:16-25; Dvir, Eden, Avolio \& Shamir, 2002:735-744; Welford, 2002:7-11; Kane \& Tremble, 2000:137-160; Robbins, 2000:471), and also (to a lesser extent) in similar organisations in South Africa (Hellriegel, Jackson, Slocum \& Staude, 2001:301).

Given the fact of the failure of South African large-scale enterprises to sustain the economic growth rate established in the 1960s and early 1970s, expectations have been directed at the SME sector (specifically from the late 1970s onwards) to increase economic activities (Frese \& Friedrich, 2002:vi). Yet, research evidence suggests inadequate leadership and management skills as primary reasons for the failure of SMEs (Anderson, 2002:3; Davies, Hides \& Powell, 2002:407, Ibrahim \& Soufani, 2002:421; Hisrich \& Drnovsek, 2002:174; CEML, 2002:2; Hodgetts \& Kuratko, 2000:15-17; Henriksen, 1999:215).

Humphries and Einstein (2003:86), Pounder (2001:6), Hinkin and Tracey (1999:105), Den Hartog, Van Muijen and Koopman (1997:20) and Bass (1990:21-22) characterise the transformational leader as someone who achieves results in one (or more) of the following ways by exerting, executing and accomplishing the key elements of transformational leadership through:

- $\quad$ charisma (idealised influence) by providing a vision and sense of mission, instilling pride, gaining respect and trust;

- $\quad$ inspiring and communicating high expectations by using symbols to focus efforts and expressing important purposes in simple ways;

- $\quad$ intellectually stimulating staff by promoting intelligence, rationality and careful problem-solving; and,

- $\quad$ catering for individualised consideration by giving personal attention, treating each employee individually, coaching and advising,

whereas Tichy and Ulrich (1984:66) argue that ' $\ldots$. [the] transformational leader must possess a deep understanding of organizations and their place in society and the life of individuals ... [and] ... they need to understand concepts of equity, power, freedom, and the dynamics of decisionmaking'.

The literature unequivocally indicates that transformational leadership is a behavioural process which can be learned (Pounder, 2003:6-13, Brown \& Posner, 2001:274-280; Kent, Crotts \& Azziz, 2001:221-229; Barling, Slater \& Kelloway, 2000:157-161; Kelloway \& Barling, 2000:355; Kelloway, Barling \& Helleur, 2000:145-149; De Coning, 1992:55; Bass, 1990:19\&31; Avolio \& Bass, 1987:85; MacMillan, 1987:450-453; Bass, Waldman, Avolio \& Bebb, 1987:7378; Tichy \& Devanna, 1986:27).

The implication of transformational leadership as a behavioural process is tantamount to the fact that SME entrepreneurs can learn the techniques and obtain the qualities they need to become transformational leaders. In other words, SME entrepreneurs can become transformational leaders who inspire, energise and intellectually stimulate their employees.

In addition to research by House, Spangler and Woycke (1991:364-395) and Kets de Vries (1994:73-93) on the types of behaviours exhibited by transformational leaders and Tichy and Devanna's (1986:30-32; 1990:271-281) profiling of a number of common characteristics that transformational leaders share, factor analytic studies by Pearce, Sims, Cox, Ball, Schnell, Smith and Trevino (2003), Kent et al. (2001), Hater and Bass (1988), Seltzer and Bass (1990) and Bass (1985) suggest that transformational leadership can be conceptually organised along four correlated dimensions.

These characteristics (as depicted in Table 2) are: idealised influence (charismatic/ visionary leadership), inspirational leadership, intellectual stimulation and individualised consideration. These four dimensions of transformational leaders form the basis of the constructs for the item pool in the questionnaire on transformational leadership characteristics in SMEs. 
Table 2: Constructs of transformational leadership

Charisma (Idealised Influence): The ability to articulate and provide vision and a sense of mission, instilling pride and value in the firm, and gaining respect and trust.

Inspiration: The extent to which the leader communicates high expectations, using symbols to focus efforts and to express important issues in simple ways.

Intellectual stimulation: The degree to which the leader promotes intelligence, rationality and careful problem-solving.

Individualised consideration: The extent to which the leader gives personal attention, treats employees individually, coaches and advises them.

Source: Bass, B.M. 1985. Leadership: Good, Better, Best. Organizational Dynamics. Winter:26-40.

Kao (1989:97) states that numerous attempts have been made to identify essential characteristics of entrepreneurs, by using a trait approach; other research examines entrepreneurship from an economic perspective (Nooteboom, 2003; Nooteboom, 2000) and even from the entrepreneur's personality which is largely based on psychoanalytical theory. Each of these approaches is discussed briefly:

From a social psychological perspective (which places the entrepreneur within the wider social environment) acknowledgement is given to factors such as family and social background, education, religion, culture, work and general life experiences as factors that impact on the entrepreneurial effort. Data on the origins of the entrepreneur are extensively based on research conducted by Kao (1989:99), Kets de Vries (1977:34-57) and Zaleznik (1976).

Secondly, from a behavioural approach, the entrepreneur is viewed in terms of a set of activities associated with the venture (Carson et al., 1995:50). The behavioural approach focuses on what the entrepreneur does and how well he does it; in other words, how attitudes, behaviours, management skills and experience combine in determining entrepreneurial success. Timmons, Smollen and Dingee (1990) suggest certain common behaviours and attitudes shared by successful entrepreneurs. The most important of these are hard-working, energetic, commitment and determination, ambition, competitiveness, excelling and winning.

Thirdly, from a psychological perspective, researchers have attempted to develop an understanding of the entrepreneur by focusing on a set of personality traits and characteristics. In an extensive literature review from 1848 to date on more than 50 studies completed by the year 1977 (cf. Timmons, Smollen \& Dingee, 1977), followed by further secondary and primary research (cf. Timmons, Smollen \& Dingee, 1990; Timmons, 1994) on entrepreneurship, six dominant themes on the characteristics of entrepreneurs can now be presented.

However, in 1977 Timmons et al. (1977:79-83) published their seminal manuscript on the characteristics of entrepreneurs in which the authors state that they had 'examined the available research and theory about the behavioral and other characteristics of successful entrepreneurs and new ventures'. It is interesting to note that Timmons et al. (1977:80) state that in distilling these entrepreneurial characteristics from the literature, '... enough agreement was at least implicit in our investigation to identify 14 dominant characteristics of successful entrepreneurs'.

Timmons et al. (1977:83) conclude in their research that they were unable to identify a single entrepreneur possessing all 14 of these dimensions to an extremely high degree.

Timmons (1994:190-197) revisits the dimensions of entrepreneurship. After having carefully consulted the literature on entrepreneurial characteristics, Timmons (1994:190-191) states that 'there are "themes" that have emerged from what successful entrepreneurs do and how they perform'. As with his (and his colleagues') earlier research (cf. Timmons et al., 1977:79-83; Timmons et al., 1990:165-170; Timmons, 1999: 191) Timmons \& Spinelli (2004:249-256) unequivocally state that there is general consensus that six dominant themes have emerged from the original 14 characteristics, as postulated earlier.

These six dominant themes (together with their concomitant attitudes/behaviours) as presented in Table 3 are: 1) commitment and determination; 2) leadership; 3) opportunity obsession; 4) tolerance of risk, ambiguity and uncertainty; 5) creativity, self-reliance and the ability to adapt; and, 6) motivation to excel. These six themes were utilised as the constructs and developed for the item pool on entrepreneurship characteristics in SMEs in the questionnaire, as identified in Table 3. In addition, the researchers developed the attitudes or behaviours for each of these 6 themes, as presented in the same table.

These operational definitions and characteristics of transformational leaders and entrepreneurs, as well as the elements constituting each dimension, are presented in Table 4 in summary. 
Table 3: Constructs of entrepreneurship

\begin{tabular}{|c|c|}
\hline Theme & Attitude or Behaviour \\
\hline Commitment and determination & $\begin{array}{l}\text { Tenacious and decisive, able to recommit/commit quickly } \\
\text { Discipline } \\
\text { Persistence in problem-solving } \\
\text { Willingness to undertake personal sacrifice } \\
\text { Immersed }\end{array}$ \\
\hline Leadership & $\begin{array}{l}\text { Self-starter; high standards but not perfectionists } \\
\text { Team builder and hero maker; inspires others } \\
\text { treat others as you want to be treated } \\
\text { Share the wealth with all the people who helped to create it } \\
\text { Integrity and reliability; builder of trust; practices fairness } \\
\text { Not a lone wolf } \\
\text { Superior learner and teacher } \\
\text { Patience and urgency }\end{array}$ \\
\hline Opportunity obsession & $\begin{array}{l}\text { Having intimate knowledge of customers' needs } \\
\text { Market driven } \\
\text { Obsessed with value creation and enhancement }\end{array}$ \\
\hline $\begin{array}{l}\text { Tolerance of risk, ambiguity and } \\
\text { uncertainty }\end{array}$ & $\begin{array}{l}\text { Calculated risk taker } \\
\text { Risk minimiser } \\
\text { Risk sharer } \\
\text { Manages paradoxes and contradictions } \\
\text { Tolerance of uncertainty and lack of structure } \\
\text { Ability to resolve problems and integrate solutions }\end{array}$ \\
\hline $\begin{array}{l}\text { Creativity, self-reliance and ability } \\
\text { to adapt }\end{array}$ & $\begin{array}{l}\text { Non-conventional, open-minded, lateral thinker } \\
\text { Restlessness with status quo } \\
\text { Ability to adapt and change; creative problem-solver } \\
\text { Ability to learn quickly } \\
\text { Lack of fear of failure } \\
\text { Ability to conceptualise and "sweat details" (helicopter mind) }\end{array}$ \\
\hline Motivation to excel & $\begin{array}{l}\text { Goal-and results orientation; high but realistic goals } \\
\text { Drive to achieve and grow } \\
\text { Low need for status and power } \\
\text { Interpersonally supporting (versus competitive) } \\
\text { Aware of weaknesses and strengths } \\
\text { Having perspective and sense of humour }\end{array}$ \\
\hline
\end{tabular}

Source: Timmons, J.A. \& Spinelli, S. 2004. New venture creation: Entrepreneurship for the $21^{\text {st }}$ century. Boston: Irwin McGraw-Hill., p. 250.

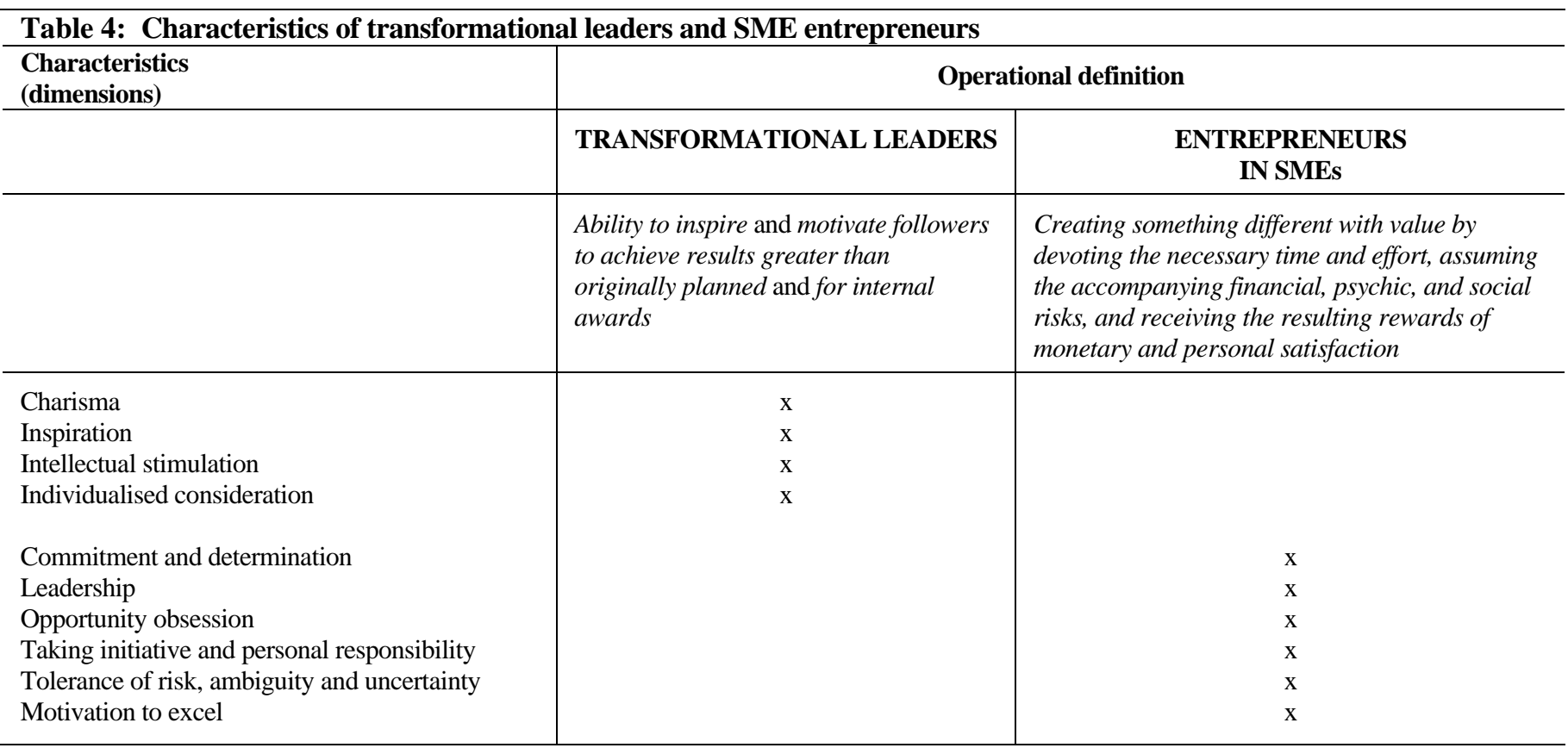




\section{Development of a questionnaire}

The principle objective of the questionnaire was to develop a sufficiently large pool of items for each of the ten dimensions (i.e. four dimensions on Transformational Leadership and six dimensions on Entrepreneurship), to allow for the omission of ambiguous and uncertain statements. A panel of 15 experts was requested to indicate the extent to which each statement (item) described the dimension under review. The panel was requested to inspect and evaluate each statement in order to ensure that the items were clear and that no overlaps occurred and that no items were repeated (Smit, 1991:155).

Table 5 presents a summary of the distribution of items per dimension. For the ten dimensions, a total number of 112 items were produced, i.e. on average 11 items per dimension.

In creating this pool of items, the standard set of rules for item writing was observed (Oppenheim, 1992:128-130, 179-181). The questionnaires were analysed for grammatical correctness and all tabulated to identify those responses which presented the biggest possible chance for ambiguity. These items were removed. In addition, items that were indicated to be corrected by the panel were corrected and retained in the pool (Oppenheim, 1992:179-181; Scott \& Wertheimer, 1967:133).

For the final questionnaire 85 items of the 112 items from the preliminary questionnaire were retained, with between six and ten items per dimension. In writing the items for inclusion into the pool of the final questionnaire, the constructional steps for pool items (Kline, 1986:113-114; Nunnally, 1978:605) were followed in that approximately half the questions were written as positive statements, with the other half as negative statements. The latter procedure is also useful in combating acquiescence (Oppenheim, 1992:181). The number of items per dimension satisfied the requirement that approximately one and a half times as many items should be included as planned for the final questionnaire (Smit, 1991:155).

These 85 items were subsequently randomly reorganised into a Likert-type scale which consists essentially of statements, followed by seven-point rating scales indicating the participants' agreement with them. Nunnally (1978:595) and Kline (1986:114) both assert that reliability increases with the number of scale points, but tends to level off at about seven points. By so doing, a balance was struck between reliability on the one hand and practical common sense on the other, which dictates that a large number of scale points would cause respondents difficulty in deciding which point to select. Nunnally (1978:594-595) also maintains that a graphic scale with numbers is preferable. Finally, the questionnaire was also translated into Afrikaans.

\section{Population and sample}

In order to incorporate SMEs on a national basis, it was decided to utilise the comprehensive database of the Bureau of Market Research (BMR) at the University of South Africa. It was decided to focus on Status Code 5 enterprises in the BMR databank - this category of enterprises is in compliance with the definition for small and medium-sized enterprises as promulgated by the Small Business Act of 1996 (Act \#102 of 1996). Since the other two quantitative factors (i.e. annual sales and net assets) can be influenced by economic factors such as inflation and interest rate fluctuations, it was decided to use the number of employees as the criterion for selecting the sample.

The decision as outlined above is also in support of the argument pertaining to SMEs that are most likely to benefit from sound transformational leadership, namely those SMEs with growth potential. For this purpose, the size of the SME comes into play in terms of its inclusion in the sample. Informal and survivalist enterprises are therefore excluded. The minimum size of an SME, as a yardstick for inclusion in this study, is also indicative of the fact that individual sample elements should have achieved a relative measure of success, i.e. they should have successfully attained a certain size before they can be included in this study.

Six industry clusters selected were as follows: construction, export, import, manufacturing, trade (retail and wholesale) and business services, as indicated in Table 6 .

From its database the BMR was requested to draw a random sample of a total of 3000 SMEs (cf. Czaja \& Blair, 1996), as indicated per industry in Table 6. During the second week of November 1999, 3000 questionnaires were mailed to SMEs in South Africa. After a follow-up, a total of 668 questionnaires, were returned. This represents a response rate of $22,3 \%$. The returns by each of the six sectors in the sample of questionnaires are presented in Table 7. It is clear that the sectoral distribution of the sample closely resembles that of the population sampled. 
Table 5: Summary of the item pool per dimension

Dimension

Number of items in pool

Transformational leadership

1. Idealised influence

2. Intellectual stimulation

3. Inspirational leadership

4. Individualised consideration

\begin{tabular}{|l|l}
12 & \\
11 & \\
\hline 13 & \\
\hline$\underline{10}$ & $\underline{46}$ \\
\hline
\end{tabular}

Entrepreneurship

\begin{tabular}{ll|c|c}
\hline 5. & Commitment and determination & 11 & 12 \\
\hline $6 . \quad$ Leadership & 10 & \\
\hline $7 . \quad$ Opportunity obsession & 11 & \\
\hline $8 . \quad$ Tolerance of risk, ambiguity and uncertainty & 12 & \\
\hline $9 . \quad$ Creativity, self-reliance and ability to adapt & $\underline{10}$ & $\underline{66}$ \\
\hline $10 . \quad$ Motivation to excel & 112 \\
\hline Total & & 12 & 12 \\
\hline
\end{tabular}

Table 6: BMR Universe and sample of Code 5 enterprises - 1999

\begin{tabular}{l|c|c|r}
\hline \multicolumn{1}{c|}{$\begin{array}{c}\text { Industry/ } \\
\text { Cluster }\end{array}$} & BMR Universe & Industry \% of Universe & Sample size \\
\hline Construction & 4106 & 9 & 274 \\
\hline Export & 1400 & 3 & 92 \\
\hline Import & 3500 & 7 & 213 \\
\hline Manufacturing & 9860 & 20 & 609 \\
\hline Services & 3000 & 6 & 136 \\
\hline Trade & 26500 & 55 & 1675 \\
\hline TOTAL & 48366 & 100 & 3000 \\
\hline
\end{tabular}

Table 7: Response rate to mailed questionnaires

\begin{tabular}{|c|c|c|c|c|c|}
\hline \multirow[b]{2}{*}{ Industry } & \multicolumn{2}{|c|}{ Questionnaires mailed } & \multicolumn{2}{|c|}{ Questionnaires returned } & \multirow{2}{*}{$\begin{array}{c}\text { \% returned } \\
\text { per Industry }\end{array}$} \\
\hline & $\mathrm{N}$ & $\%$ & $\mathrm{~N}$ & $\%$ & \\
\hline Construction & 274 & 9,1 & 74 & 11,1 & 27,0 \\
\hline Export & 92 & 3,1 & 30 & 4,5 & 32,6 \\
\hline Import & 213 & 7,1 & 45 & 6,7 & 21,1 \\
\hline Manufacturing & 609 & 20,3 & 132 & 19,8 & 21,7 \\
\hline Service & 136 & 4,5 & 35 & 5,2 & 25,9 \\
\hline Trade & 1675 & 55,8 & 352 & 52,7 & 21,0 \\
\hline Total & 3000 & 100,0 & 668 & 100,0 & 22,3 \\
\hline \multicolumn{3}{|l|}{ Unusable returns } & 283 & & \\
\hline \multicolumn{3}{|l|}{ Address unknown } & 207 & & \\
\hline \multicolumn{3}{|l|}{ Business relocated } & 26 & & \\
\hline \multicolumn{3}{|l|}{ Business closed } & 41 & & \\
\hline \multicolumn{3}{|c|}{ Refused to participate } & 5 & & \\
\hline \multicolumn{3}{|c|}{ Questionnaire grossly incomplete } & 4 & & \\
\hline
\end{tabular}

\section{Statistical analysis}

As a first step factor analysis was applied to all items within a specific dimension. This was followed by an item and reliability analysis to select only those items that show internal consistency. These items were then subjected to a principal component analysis to determine the item loadings. The discriminatory ability of the items was studied by comparing the proportions of respondents who selected each response.

Four factors emerged from the measurement of Transformational Leadership, closely following the constructs of Bass (see Table 2) namely charisma (TL1), inspiration (TL2), intellectual stimulation (TL3) and individualised consideration (TL4). 
In the case of Entrepreneurship, five factors emerged from the elaborate statistical analysis. The first is called Motivation (Ent1) which is party related to the last construct in the theoretical model (see Table 3), the second is Integrity and Risk Management (Ent2), a blend of the second and third constructs in the theoretical model, the third is Cultural Integration (Ent3), followed by Knowledge of Market Opportunities (Ent4) and Market Driven Opportunities (Ent5).

\section{The relationship between entrepreneurship and transformational leadership}

Four tests were performed to determine if a relationship between entrepreneurship and transformational leadership exists, as well as to establish the nature of the relationship.

1. A correlation matrix was constructed between the subscales and the total scales of the TL and Ent factors. The correlation matrix presents a convenient way of presenting the interrelations among several variables (Babbie \& Mouton, 2001:464).
2. The respondents were categorised into one of the three groups on each of the two scales: High, Medium and Low and a contingency table was constructed.

3. Analysis of Variance (ANOVA) was done to test whether the different Entrepreneurial groups (i.e. Low, Medium, and High groups) differ from each other on their transformational leadership scores.

4. ANOVA was followed by a regression analysis to determine what the nature and strength of the relationship between Transformational Leadership and Entrepreneurship is.

The correlation matrix in Table 8 indicates the relationship for each of the factors of entrepreneurship with each of the factors of transformational leadership, as well as the intercorrelation between the totals for these two dimensions.

Table 8: Correlation matrix for the dimensions of Entrepreneurship and Transformational Leadership

\begin{tabular}{c|l|c|c|c|c|c|c}
\hline & & Ent1 & Ent2 & Ent3 & Ent4 & Ent5 & Ent Total \\
\hline \multirow{2}{*}{ TL1 } & $\begin{array}{l}\text { Correlation } \\
\text { Coefficient }\end{array}$ & 0,501 & 0,116 & 0,296 & 0,230 & 0,116 & 0,516 \\
\cline { 2 - 9 } & Sig. (2-tailed) & 0,000 & 0,000 & 0,000 & 0,000 & 0,007 & 0,000 \\
\hline \multirow{2}{*}{ TL2 } & $\begin{array}{l}\text { Correlation } \\
\text { Coefficient }\end{array}$ & 0,470 & 0,470 & 0,299 & 0,255 & 0,105 & 0,529 \\
\cline { 2 - 9 } & Sig. (2-tailed) & 0,000 & 0,000 & 0,000 & 0,000 & 0,015 & 0,000 \\
\hline \multirow{2}{*}{ TL3 } & $\begin{array}{l}\text { Correlation } \\
\text { Coefficient }\end{array}$ & 0,439 & 0,404 & 0,246 & 0,239 & 0,097 & 0,473 \\
\cline { 2 - 9 } & Sig. (2-tailed) & 0,000 & 0,000 & 0,000 & 0,000 & 0,025 & 0,000 \\
\hline \multirow{2}{*}{ TL4 } & $\begin{array}{l}\text { Correlation } \\
\text { Coefficient }\end{array}$ & 0,409 & 0,346 & 0,265 & 0,191 & 0,050 & 0,430 \\
\cline { 2 - 9 } & Sig. (2-tailed) & 0,000 & 0,000 & 0,000 & 0,000 & 0,252 & 0,000 \\
\hline \multirow{2}{*}{ Total } & $\begin{array}{l}\text { Correlation } \\
\text { Coefficient }\end{array}$ & 0,540 & 0,480 & 0,310 & 0,266 & 0,100 & 0,571 \\
\cline { 2 - 9 } & Sig. (2-tailed) & 0,000 & 0,000 & 0,000 & 0,000 & 0,0202 & 0,000 \\
\hline
\end{tabular}

Correlations are all significant at the .01 level (2-tailed).

Note: $\mathrm{N}=535$

Based on the data in Table 8, the following broad-based findings regarding the relationship between entrepreneurship and transformational leadership in SMEs in a South African context are made:

cd

- A medium degree of positive relationship exists between entrepreneurship and transformational leadership ( $r=0,571)$; viewed differently, owners and managers of South African SMEs possess characteristics that are both of entrepreneurs and of transformational leaders;

- Charisma (idealised influence) as a transformative characteristic correlates positively to a medium degree ( $r=0,516)$ with entrepreneurship;

- Similarly, inspiration as the second transformative characteristic correlates positively to a medium degree $(r=0,529)$ with entrepreneurship;
- The third element of transformational leadership, i.e. intellectual stimulation, correlates positively to a medium degree $(r=0,473)$ with entrepreneurship; and,

- Individualised consideration as the fourth factor of transformational leadership also correlates positively to a medium positive degree $(r=0,430)$ with entrepreneurship.

It is also evident that Ent1 and Ent2 correlate fairly moderately with all the transformational leadership factors (correlation coefficients $>0,4$ ). This does not seem to be the case for Ent3, Ent4 and Ent5, which all show relative small correlation coefficients.

The total scores on each of these two variables have been categorised into the lowest third, middle third and highest third from the cumulative percentage scores. 
The contingency table that emerged from this categorisation is reported in Table 9.

There seems to be strong evidence to suggest that a significant positive relationship exists between the entrepreneurship and transformational leadership variables.

Because the transformational leadership score distribution for the High Ent group is not normal, an Analysis of Variance could not be performed.

The non-parametric Kruskal-Wallis Test was applied to test for differences between the means of these groups (High, Medium, and Low). The test indicates (Table 10) that at least one of the group locations differs from the rest.

In order to be able to explain if the values (characteristics) of transformational leadership can be explained in terms of the values (characteristics) of entrepreneurship (or to use the argument that entrepreneurship is a co-producer of transformational leadership), regression analysis is applied. The results of regression analysis are presented in Table 11.

The data in Table 11 indicate that $39,71 \%$ of the values of transformational leadership can be explained by the entrepreneurship variable.

\section{Table 9: Contingency table}

\begin{tabular}{|c|c|c|c|c|c|}
\hline & & \multicolumn{4}{|c|}{ Transformational Leadership } \\
\hline & & Low & Med & High & Total \\
\hline \multirow{8}{*}{ Entrepreneurship } & Low & 113 & 52 & 17 & 182 \\
\hline & \% of Ent total & 62,1 & 28.6 & 9,3 & 100 \\
\hline & Medium & 52 & 77 & 61 & 190 \\
\hline & $\%$ of Ent total & 27,4 & 40.5 & 32,1 & 100 \\
\hline & High & 20 & 44 & 99 & 163 \\
\hline & \% of Ent total & 12,3 & 27,0 & 60,7 & 100 \\
\hline & Total & 185 & 173 & 177 & 535 \\
\hline & \% of Ent total & 34,6 & 32,3 & 33,1 & 100 \\
\hline
\end{tabular}

Test Statistic $\chi^{2}=141,064$

$\mathrm{p}$-Value $=0,000$

Tablw 10: Kruskal-Wallis test

\begin{tabular}{l|c|c|r}
\hline Sample & RankSum & SampSize & \\
\hline Ent Low & 29973,5 & 182 & Test Statistic H = 149,7655 \\
\hline Ent Med & 53577,0 & 190 & P-Value $=0,000$ \\
\hline Ent High & 59829,5 & 163 & \\
\hline
\end{tabular}

Table 11: Summary output of regression analysis between entrepreneurship and transformational leadership

\begin{tabular}{l|c|c}
\hline \multicolumn{2}{c}{ Regression Statistics } \\
\hline Multiple R & 0,630140396 & \\
R Square & 0,397076919 & \\
Adjusted R Square & 0,395945731 & \\
Standard Error & 20,3150859 & \\
Observations & 535 & \\
\hline
\end{tabular}

Analysis of Variance

\begin{tabular}{|c|c|c|c|c|c|}
\hline & df & SS & MS & $\mathbf{F}$ & Significance F \\
\hline \multirow{4}{*}{$\begin{array}{l}\text { Regression } \\
\text { Residual } \\
\text { Total } \\
\end{array}$} & 1 & 144869.6 & 144869,6 & \multirow[t]{3}{*}{351,0265} & \multirow[t]{3}{*}{0,000} \\
\hline & 533 & 219970.5 & 412,7027 & & \\
\hline & 534 & 364840.1 & & & \\
\hline & Coefficients & Standard Error & t Stat & \multicolumn{2}{|r|}{ P-value } \\
\hline \multirow{2}{*}{$\begin{array}{l}\text { Intercept } \\
\text { Ent Total }\end{array}$} & 46,66324619 & 9,064873 & 5,1477 & \multirow{2}{*}{\multicolumn{2}{|c|}{$\begin{array}{l}0,000 \\
0,000\end{array}$}} \\
\hline & 2,302320858 & 0,122884 & 18,7357 & & \\
\hline
\end{tabular}

Finally, the conclusion is that those entrepreneurs with high scores on entrepreneurship also have high scores on transformational leadership.

\section{Implications and recommendations}

In order to conclude the discussion on the formulation of a broad development approach for SMEs to equip their leadership with a framework for strategic renewal, the following suggestions are made.

As a point of departure, it has been recognised that the entrepreneurs in SMEs function on the basis of 'short-term mindedness' (Boocock, Loan-Clarke, Smith \& Whittaker, 1999:184; Smith \& Whittaker, 1998:176) and that this process can be influenced by means of including and 
incorporating adaptations of a strategic nature (Irwin, 2000:255-260).

The findings suggest that the profile elements for strategic behaviour in SMEs can be acquired and developed by means of a number of interventions.

In the context of transformational leadership in SMEs in this research project at the macro level, elements of transformational leadership can be promoted by government within its appropriate structures in view of its acceptance of the importance of SMEs to economic development and growth (Foxcroft, Wood, Kew, Herrington \& Segal, 2002:4; Dobson, 2002:23; DTI Annual Report, 200-2001:6; Nieman, 2001:445; Boocock et al., 1999:187; Smith \& Whittaker, $1998: 177,184)$, by interventionist policies targeted at those entrepreneurs with growth ambitions (Irwin, 2000:255), and by means of more formal education opportunities at institutions of higher learning (Foxcroft et al., 2002:11; Perren \& Grant 2001:16)

At the intermediate (meso) level, elements of transformational leadership can be acquired, inter alia, by establishing network for support and advice (Irwin, 2000:180; Perren \& Grant, 2001:8), by forming partnerships with already existing organisations to strengthen the impact through synergy (Boocock et al., 1999:187), by acquiring membership of external organisations in order to be exposed to trends and developments (Thomson \& Gray, 1999:113), by sharing experiences at informal forums (Perren \& Grant, 2001:12), and by consistently developing one's skills levels (Boocock et al., 1999:187).

At the internal (micro) level entrepreneurs can acquire elements of transformational leadership by adapting from an entrepreneurial approach to a more professional approach (Irwin, 2000:368), by becoming motivated and nurturing one's driving factors (Rae \& Carswell, 2001:156), and by listening to and learning from success stories (Boocock et al., 1999:187), and by utilising the knowledge and skills of appropriate business consultants (Irwin, 2000:255).

In terms of this multi-development framework, the outcome is reflected on the newly-acquired transformational leadership knowledge and skills of the new SME transformational leader.

For entrepreneurs the process of extending and renewal implies providing leadership; providing a vision and developing this vision in others in the enterprise; building and managing entrepreneurial teams; providing appropriate structures in the enterprise to facilitate work; planning for change and acting as a catalyst to ensure progress; identifying clear goals and taking action to achieve these; acquiring appropriate skills to lead the enterprise through the possesses of change; and, gaining access, through networking, to the necessary resources to implement change. The whole process implies the implementation of the concept of transformational leadership by the entrepreneur.

\section{Conclusion}

Based on the fact that published evidence of a quantitative nature (premised on empirical evidence of the implementing and practising of transformational leadership in SMEs) both nationally and internationally is altogether absent, the findings of this survey presents challenges for further research.

The question as to whether entrepreneurs and entrepreneurship can be considered as subsets of respectively transformational leadership and transformational behaviour, remains unresolved - as is the case with the opposite position where respectively transformational leadership and transformational behaviour can be considered as subsets of entrepreneurship. The research findings do, however, clearly indicate that a clear relationship exists between the two concepts.

The finding makes perfect sense considering the pivotal role that SME entrepreneurs have to play in the socio-economic transformation of societies. It therefore follows logically that entrepreneurs should display at least some of the profile attributes associated with transformational leaders.

In similar vein, transformational leaders need the ability to innovate, to pioneer new paradigms and to move beyond the boundaries of direct predictability - profile attributes that are deemed to be of key importance to entrepreneurs. A dynamic interrelationship between these two key concepts is therefore apparent and this should be taken full cognisance of in the development of both transformational leaders and entrepreneurs.

\section{Referencesy}

Anderson, S. 2002. Joining entrepreneurs in their world: Improving entrepreneurship, management and leadership in UK SMEs. London: Council for Excellence in Management and Leadership.

Avolio, B.J. \& Bass, B. 1987. 'Transformational leadership, charisma, and beyond'. In Hunt, J.G., Baliga, B.R., Dachler, H.P. \& Schriesheim, A. (Eds.). 1987. Emerging leadership vistas. Massachusetts: Lexington.

Babbie, E. \& Mouton, J. 2001. The practice of social research. Cape Town: Oxford University.

Barling, J., Slater, F. \& Kelloway, E.K. 2000. 'Transformational leadership and emotional intelligence: an exploratory study', Leadership \& Organization Development Journal, 21(3):157-161.

Bass, B.M. 1990. 'From transactional to transformational leadership: Learning to share the vision', Organizational Dynamics, 18(3):19-31.

Bass, B.M. 1985. Leadership and performance beyond expectations. New York: Free Press.

Bass, B.M. \& Avolio, B.J. (Eds.). 1994. Improving organizational effectiveness through transformational leadership. Thousand Oaks, California: Sage. 
Bass, B.M., Waldman, D.A., Avolio, B.J. \& Bebb, M. 1987. 'Transformational leadership and the falling dominoes effect', Group \& Organization Studies, 12(1):73-78.

Bennis, W. 1982. 'Leadership transforms vision into action', Industry Week, May 31:54-56.

Berry, A., Von Blotnitz, M., Cassim, R., Kesper, A., Rajaratnam, B. \& Van Sevenster, D. 2002. 'The economics of SMMEs in South Africa', Trade and Industry Policy Strategies. Pretoria: Department of Trade and Industry.

Boocock, J.G., Loan-Clarke, J., Smith, A.J. \& Whittaker, J. 1999. 'Management training and development in small and medium-sized enterprises: An assessment of the effectiveness of Training and Enterprise Councils in the East Midlands', Journal of Small Business and Enterprise Development, 6(2):178-190.

Brown, L.M. \& Posner, B.Z. 2001. 'Exploring the relationship between learning and leadership', Leadership \& Organization Development Journal, 22(6):274-280.

Bryman, A. 1992. Charisma and leadership in organizations. London: Sage.

Carson, D., Cromie, S., McGowan, P. \& Hill, J. 1995. Marketing and entrepreneurship in SMEs: An innovative approach. London: Prentice-Hall.

CEML (Council for Excellence in Management and Leadership). 2002. Managers and leaders: raising our game. London: The Council for Excellence in Management and Leadership, Department of Trade and Industry.

Cromie, S. 2000. 'Assessing entrepreneurial inclinations: Some approaches and empirical evidence', European Journal of Work and Organisational Psychology, 9(1):7-30.

Czaja, R. \& Blair, J. 1996. Designing surveys: A guide to decisions and procedures. Thousand Oaks: Pine Forge.

Davies, J., Hides, M. \& Powell, J. 2002. 'Defining the development needs of entrepreneurs in SMEs', Education + Training, 44(8/9):406-412.

De Coning, T.J. 1992. 'Transformational leadership in SMEs', Southern African Journal for Entrepreneurship and Small Business, 4(2):52-59.

Den Hartog, D.N., Van Muijen, J.J. \& Koopman, P.L. 1997. 'Transactional versus transformational leadership: An analysis of the MLQ', Journal of Occupational and Organizational Psychology, 70(1):19-29.

Denton, M. \& Vloeberghs, D. 2003. 'Leadership challenges for organisations in the New South Africa', Leadership \& Organization Development Journal, 24(2):84-95.

Dobson, W. 2002. 'A guide to the microeconomic reform strategy - A discussion paper from the Department of Trade and Industry'. Pretoria, DTI.
Driver, A., Wood, E., Segal, N. \& Herrington, M. 2001. Global entrepreneurship monitor: 2001 South African executive report. Cape Town: Graduate School of Business, University of Cape Town.

DTI (Department of Trade and Industry) Annual Report 2000-2001. Pretoria: DTI.

Dvir, T., Eden, D., Avolio, B.J. \& Shamir, B. 2002. 'Impact of transformational leadership on follower development and performance: A field experiment', Academy of Management Journal, 45(4):735-744.

Dvir, T. \& Shamir, B. 2003. 'Follower developmental characteristics as predicting transformational leadership: A longitudinal study', Leadership Quarterly, 14(3):327-344.

Foxcroft, M.L., Wood, E., Kew, J., Herrington, M. \& Segal, N. 2002. Global entrepreneurship monitor: 2002 South African executive report. Cape Town: Graduate School of Business, University of Cape Town.

Frese, M. \& Friedrich, C. 2002. 'From the editors of the special issue on entrepreneurship in Africa', Journal of Developmental Entrepreneurship, 7(3):v-339.

Hater, J.J. \& Bass, B.M. 1988. 'Superiors' evaluations and subordinates' perceptions of transformational and transactional leadership', Journal of Applied Psychology, 73:695-702.

Hellriegel, D., Jackson, S.E., Slocum, J.W. \& Staude, G. 2001. Management. Cape Town: Oxford University.

Henriksen, L. 1999. 'Small firms and economic development: Research, policy and practice', Journal of Small Business and Enterprise Development, 6(3):215-218.

Hinkin, T.R. \& Tracey, J.B. 1999. 'The relevance of charisma for transformational leadership in stable organizations', Journal of Organizational Change Management, 12(2):105-19.

Hisrich, R.D. \& Drnovsek, M. 2002. 'Entrepreneurship and small business research - a European perspective', Journal of Small Business and Enterprise Development, 9(2):172-222.

Hodgetts, R.M. \& Kuratko, D.F. 2000. Effective small business management. Orlando, Florida: Harcourt Brace Jovanovich.

House, R.J., Spangler, W.D. \& Woycke, J. 1991. 'Personality and charisma in the US presidency: A psychological theory of leader effectiveness', Administrative Science Quarterly, 36:364-395.

Humphries, J.H. \& Einstein, W.O. 2003. 'Nothing new under the sun: Transformational leadership from a historical perspective', Journal of Management History, 41(1):85-95.

Ibrahim, A.B., Soufani, K. 2002. 'Entrepreneurship education and training in Canada: A critical assessment', Education + Training, 44(8/9):421-430. 
Irwin, D. 2000. 'Severn ages of entrepreneurship', Journal of Small Business and Enterprise Development, 7(3):255-260.

Kane, T.D. \& Tremble, T.R. 2000. 'Transformational leadership effects at different levels of the army, Military Psychology, 12(2):137-160.

Kao, J. 1989. Entrepreneurship, creativity, \& organization: Text, cases \& readings. Englewood Cliffs: Prentice-Hall.

Kelloway, E.K. \& Barling, J. 2000. 'What we have learned about developing transformational leaders', Leadership \& Organization Development Journal, 21(7):355-362.

Kelloway, E.K., Barling, J. \& Helleur, J. 2000. 'Enhancing transformational leadership: The roles of training and feedback', Leadership \& Organization Development Journal, 21(3):145-149.

Kent, T.W., Crotts, J.C. \& Azziz, A. 2001. 'Four factors of transformational leadership behaviour', Leadership \& Organization Development Journal, 22(5):221-229.

Kets de Vries, M.F.R. 1994. 'The leadership mystique', Academy of Management Executive, 8(3):73-93.

Kets de Vries, M.F.R. 1977. 'The entrepreneurial personality: A person at the crossroads', Journal of Management Studies, 14:34-57.

Kline, P. 1986. A handbook for test construction. New York: Methuen.

Larsson, G., Carlstedt, L., Andersson, J., Andersson, L., Danielsson, E., Johansson, A., Johansson, E., Robertsson, I. \& Michel, P. 2003. 'A comprehensive system for leaders evaluation and development,' Leadership and Organization Development Journal, 24(1):16-25.

Lussier, R.N. 2003. Management fundamentals: Concepts, applications, skill development. Mason, Ohio: Thomson.

MacMillan, I.C. 1987. 'New business development: A challenge for transformational leadership', Human Resource Management, 26(4):439-454.

Nadler, D.A. \& Tushman, M.L. 1990. 'Beyond the charismatic leader: Leadership and organizational change', California Management Review, Winter, 32(2):77-97.

Nieman, G. 2002. 'Training entrepreneurs and small business enterprises in South Africa: A situational analysis', Education + Training, 43(8/9):445-450.

Nooteboom, B. 2003. Stages of discovery and entrepreneurship. Rotterdam: Erasmus Research Institute of Management, Rotterdam School of Management, Erasmus University. Research in Management Series, Report \# ERS2003-028-ORG.

Nooteboom, B. 2000. Learning and innovation in organizations and economies. Oxford: Oxford University.
Nunnally, J.C. 1978. Psychometric theory. New York: MacGraw-Hill.

Oppenheim, A.N. 1992. Questionnaire design, interviewing and attitude measurement. London: Printer.

Pearce, C.L., Sims, H.P., Cox, J.F., Ball, G., Schnell, E., Smith, K.A. \& Trevino, L. 2003. 'Transactors, transformers and beyond: A multi-method development of theoretical typology of leadership', Journal of Management Development, 22(4):273-307.

Perren, L. \& Grant, P. 2001. Management and leadership in UK SMEs: Witness testimonies from the world of entrepreneurs and SME managers. London: Council for Excellence in Management and Leadership.

Pillai, R., Schriesheim, C.A. \& Williams, E.S. 1999. 'Fairness perceptions and trust as mediators for transformational and transactional leadership: A two-sample study', Journal of Management, 25:649-669.

Pounder, J.S. 2003. 'Employing transformational leadership to enhance the quality of management development instruction', Journal of Management Development, 22(1):613.

Pounder, J.S. 2001. 'New leadership and university organizational effectiveness: Exploring the relationship', Leadership and Organizational Development Journal, 22(6):281-90.

Rae, D. \& Carswell, M. 2001. 'Towards a conceptual understanding of entrepreneurial learning', Journal of Small Business and Enterprise Development, 8(2):150-158.

Robbins, S.P. 2000. Managing today! Upper Saddle River, New Jersey: Prentice Hall.

Scott, W.A. \& Wertheimer, M. 1967. Introduction to psychological research. New York: Wiley.

Seltzer, J. \& Bass, B.M. 1990. 'Transformational leadership: Beyond initiation and consideration', Journal of Management, December: 693-703.

Smit, G.J. 1991. Psigometrika: Aspekte van toetsgebruik. Pretoria: HAUM.

Smith, A. \& Whittaker, J. 1998. 'Management development in SMEs: What needs to be done?', Journal of Small Business and Enterprise Development, 5(2):176-185.

Tichy, N.M. \& Devanna, M.A. 1997. The transformational leader: The key to global competitiveness. New York: John Wiley.

Tichy, N.M. \& Devanna, M.A. 1986. 'The transformational leader’, Training and Development Journal, 40(7):27-32.

Tichy, N.M. \& Ulrich, D.O. 1984. 'The leadership challenge A call for the transformational leader', Sloan Management Review, Fall: 59-68. 
Timmons, J.A. 1999. New venture creation: Entrepreneurship for the $21^{\text {st }}$ century. Boston: Irwin McGraw-Hill.

Timmons, J.A. 1994. New venture creation. Burr Ridge, Illinois: Irwin.

Timmons, J.A., Smollen, L.E. \& Dingee, L.M. 1990. New venture creation: Entrepreneurship in the 1990s. Homewood, Illinois: Irwin.

Timmons, J.A., Smollen, L.E. \& Dingee, L.M. 1977. New venture creation: A guide to small business development. Homewood, Illinois: Irwin.

Timmons, J.A. \& Spinelli, S. 2004. New venture creation: Entrepreneurship for the $21^{\text {st }}$ century. Boston: Irwin McGraw-Hill.

Thomson, A. \& Gray, C. 1999. 'Determinants of management development in small business', Journal of Small Business and Enterprise Development, 6(2):113-127.

Visagie, J.C. 1997. 'SMME's challenges in reconstructing South Africa’, Management Decision, 35(9):660-670

Viviers, W. \& Steyn, T.F.J. 1992. 'The development of the EC-92 programme: The implications for the South African business community', Southern African Journal for Entrepreneurship and Small Business, 4(2):36-51.

Waldman, D.A. 1987. 'Management by example: Developing transformational leaders’, Business, Jul-Sep:23-28.

Welford, C. 2002. 'Transformational leadership a popular leadership style in nursing', Nursing Management - UK, 9(4):7-11.

Zaleznik, A. 1976. Power and the corporate mind. New York: Harper and Row. 
